\title{
INTRODUCTION
}

Renal failure is a condition in which the kidneys fail to remove metabolic end-products from the blood and regulate the fluid, electrolyte, and $\mathrm{pH}$ balance of the extra cellular fluids. The underlying cause may be renal disease, systemic disease, or urologic defects of non renal origin. Renal failure can occur as an acute or a chronic disorder. Zhanget al.,(2013)

Glycerol is sugar alcohol compound. It is a colorless, odorless, viscous liquid that is widely used in pharmaceutical formulations. Glycerol has three hydroxyl groups that are responsible for its solubility in water. The glycerol backbone is central to all lipids known as triglycerides. Glycerol is sweet-tasting and generally considered nontoxic. Glycerol-induced Acute Renal Failure is characterized by myoglobinuria, tubular necrosis. Karam et al.,(1995) .A standard method of inducing renal failure is byintramuscular administration of $50 \%$ glycerol, $\mathrm{v} / \mathrm{v}(8 \mathrm{ml} / \mathrm{kg}, \mathrm{im})$ Savic et al.,(2002).

Citrus aurantium L. (Rutaceae) also called Bitter orange, used as traditional Chinese medicine for more than 5,000 years Castleman,(1995). The application of fruit extract as dietary supplement for losing body weight has recently been developed, with the active constituents as adrenergic amines and flavonoids Kuboet al.,(2005). Bitter orange used in herbal medicine as a stimulant Sharpe et al., (2006), contains the tyramine metabolites Nmethyltyramine, octopamine and synephrine Gange et al., (2006). These substances are similar in action to that of epinephrine, act on the $\alpha 1$ receptors responsible for hypertension Hess and Sullivan, (2005). It had also been reported that C. aurantium has useful effects to control insect pests Siskos et al.,( 
2009), treatment of obesity and suppression of appetite Monsef-Esfahani et al., (2004), as sedative and heart tonic Calapai et al., (1999). Some of the studies showed their effectiveness on cardio vascular system, which includes; interruption in the blood pressure and excitability of cardiac muscles or adrenergic activity Fang et al., (2003). The phytochemical study of fruit peel extract was reported to contain volatile oils, limonene, flavonoids, coumarins, triterpenes, vitamin $\mathrm{C}$, carotene, and pectin. Flavonoids are being responsible for its antiinflammatory, antibacterial, and antifungal properties Jyotsna and Saonere, (2011). Stimulation of antioxidant detoxification enzyme system by Limonene helps to control cancer Satoh et al., (1996).

\section{Aim of the study}

The present study will be carried out to investigate the nephroprotectiveand therapeutic effects of citrus Aurantium on renal damage induced by glycerol in male rats as well as histopathological examination of kidneys .

\section{Materials and Methods}

\section{A- Materials:}

1-Citrus aurantium : was purchased from alocal market In the winter season,Cairo ,Egypt .

2-glycerol: was purchased from Ameriya company for Pharmaceutical and Chemical Industries, Cairo , Egypt.

\section{3- Chemicals and kits :}

Kits for biochemical analysis were purchased from the gamma trade company for pharmaceutical Chemicals, Dokki, Egypt. And chemicals were purchased from EL Gomhorya company cairo ,city ,Egypt . 


\section{4- Animals:}

Thirty five mature male albino rats of Sprague Dawley strain weighing $(175 \pm 10 \mathrm{~g})$ and $(12-14$ weeks old) were purchased from Laboratory of Animal Colony Helwan Egypt.

\section{B- Methods:-}

\section{1-Preparation of dried Citrus aurantium:-}

Fresh Citrus aurantium was washed with water and cut into slices, removed seeds and dried by the hybrid convective drying system, belonging to the Solar Energy Department, National Research Center, Dokki , Egypt, at $30-40^{\circ}$ C. Thirty kilograms of freshcitrus aurantium yielded 4.5 kilogram dried Citrus aurantium .

2- Determination of the total phenolic compounds of Citrus aurantium:-

Total phenolic concentration was analyzed using the method described by Singleton and Rossi.(1965).

\section{3- Preparation of the basal diet:}

Basal diet was prepared according to Jia et al.,(1999).

\section{4- Induction of nephrotoxicity.}

Rats injected with a single dose of glycerol $(50 \%$ $\mathrm{v} / \mathrm{v}$ glycerol in $0.9 \%$ saline at $10 \mathrm{ml} / \mathrm{kg}$ ) in the last and first days of the experiment according to Nobuhito et al.,(1999)

\section{5-Experimental Design :}

Rats were maintained under controlled hygienic conditions. Animals were fed on basal diet and water was provided ad libitum. Rats were allowed to acclimatize to the laboratory environment for 7 days before starting of the experiment. The experiment was performed on thirty five adult Sprague Dawley rats weighted $(175 \pm 10 \mathrm{~g})$ randomly distributed into 5 groups, of 7 animals each. Group (1) rats were fed on basal diet and served as a negative control, 
while groups (2) and (3) were kept as a positive control groups intoxicated by a a single dose of glycerol $(50 \% \mathrm{v} / \mathrm{v}$ glycerol in $0.9 \%$ saline at $10 \mathrm{ml} / \mathrm{kg}$ ) at the last and first days of the experiment, respectively, Groups (4) and (5) rats were fed on basal diet with $20 \%$ of Citrus aurantium ( pretreated group ) and ( treated group ), respectively for 4 weeks. Feed intake was calculated daily and body weight gain was recorded weekly. At the end of the feeding period, the rats were euthanized by prolonged exposure to ether and blood samples were withdrawn for separating the serum by centrifugation at $8000 \mathrm{rpm}$ for $15 \mathrm{~min}$. Serum samples were kept frozen at $-70 \dot{C}$ till biochemical analyses. The kidney of sacrificed rats were taken and preserved in $10 \%$ formalin solution till processed for the histopathological examination.

\section{6- Kidney function marker:}

Blood urea nitrogen was determined using Bio Mérieux kits according to Patton and Crouch,(1977) Serum uric acid was determined using the enzymatic colorimetric method as described by Fossatiet al.,(1980). Serum creatinine concentra-tions were calorimetrically determined by Husdan and Rapoport (1968). Serum total protein, albumin and homocy-steine were determined as descrebied by the method of Weichselbaum, (1946), Bartholomew and Delaney (1966) and Ueland et al.,(1999). respectively .

\section{HistopathologicalExaminations :}

The Kidney of sacrificed rats were taken and immersed in $10 \%$ formalin solution . the sections were examined according to Carleton,(1979)

\section{Statistical analysis :}

The obtained data were statistically analyzed by using computer .The results were expressed as (mean \pm standard 
Study the Protective and Therapeutic Effect of Bitter orange (Citrus aurantium .L) on Acute Renal Failure in Male Rats

deviation "SD") and tested for significance using both one way analysis of variance "ANOVA" test, according to Armitageet al.,(1987)and least significant differences "LSD" according to Scedecorand Cochran, (1976)

\section{RESULTS}

Data in table (1) showed that, total Polyphenol in Citrus aurantiumwas $1.40 \mathrm{mg} / \mathrm{g}$.

Table 1 : Total Polyphenols in dry Citrus aurantium13.1 $\mathrm{mg} / \mathrm{g}$.

\begin{tabular}{|c|c|}
\hline Parameter & $\begin{array}{c}\text { Dry matter of leave of ginkgo biloba } \\
\mathrm{g} / 100 \mathrm{~g} \mathrm{dw}\end{array}$ \\
\hline $\begin{array}{c}\text { T. Polyphenols } \\
(\mathrm{mg} \mathrm{GAE} / \mathrm{g})\end{array}$ & 13.1 \\
\hline
\end{tabular}

- GAE : gallic acid equivalents.

\section{Dw:dry weight}

Data in table (1) The phenolic material was evaluated for $100 \mathrm{~g}$ of citrus aurantiumin the National Research Center. The results showed that every $100 \mathrm{~g}$ of citrus aurantium contains $13.1 \mathrm{~g}$ of phenolic material

Data in table (2) showed that, there were very highly significant $(\mathrm{P}<0.05)$ difference between glycerol ( +ve ) and control (-ve) group in feed intake(FI). Nephrotoxic group $(+v e)$ revealed significant reduction $(\mathrm{P}<0.05)$ in final body weight) b.wt and body weight gain(BWG )\% as compared with control (-ve). Pretreated with $20 \%$ Citrus aurantium caused a signficant $(\mathrm{P}<0.05)$ reduction in final weight and BWG\% compared with glycerol (+ve ). While pretreated with $20 \%$ Citrus aurantium induced improvement in final weight and BWG \%. compared with glycerol $(+v e)$. 
Table (2): Effect of bitter orange(Citrus aurantium.L) on feed intake, weights and body weight gain $\%$ against glycerol induced nephrotoxicity in male rats.

\begin{tabular}{|c|c|c|c|c|}
\hline $\begin{array}{l}\text { Groups } \\
\text { Parameter }\end{array}$ & $\begin{array}{c}\text { Feed } \\
\text { Intake }\end{array}$ & $\begin{array}{c}\text { InitialWeight( } \\
\text { g) }\end{array}$ & $\begin{array}{c}\text { Final } \\
\text { Weight }(g)\end{array}$ & BWG\% \\
\hline G(1)-ve control & $\begin{array}{c}19.00^{\mathrm{a}} \pm \\
1.00\end{array}$ & $\begin{array}{c}202.333^{\mathrm{a}} \pm \\
4.041\end{array}$ & $\begin{array}{c}244.00^{\mathrm{a}} \pm \\
5.291\end{array}$ & $\begin{array}{c}20.590^{\mathrm{a}} \pm \\
0.523\end{array}$ \\
\hline $\begin{array}{l}\text { G(2)+ve Control } \\
\text { (pretreated) }\end{array}$ & $\begin{array}{l}18.333^{\mathbf{a}} \\
\mathbf{b}_{0.577}\end{array}$ & $\begin{array}{c}203.333^{\mathrm{a}} \pm \\
1.154\end{array}$ & $\begin{array}{c}235.666^{b} \pm \\
0.577^{b}\end{array}$ & $\begin{array}{c}15.904^{b} \pm \\
0.839\end{array}$ \\
\hline $\begin{array}{l}\text { G(3)+vecontrol } \\
\text { (treated) }\end{array}$ & $\begin{array}{c}14.00^{c} \pm \\
1.00\end{array}$ & $\begin{array}{c}202.666^{\mathrm{a}} \pm \\
2.516^{2}\end{array}$ & $\begin{array}{c}212.333^{c} \pm \\
2.51\end{array}$ & $\begin{array}{c}4.767^{\mathbf{c}} \pm \\
0.297\end{array}$ \\
\hline $\begin{array}{l}\text { G(4)pretreated } \\
\text { with } 20 \% \text { Citrus } \\
\text { aurantium }\end{array}$ & $\begin{array}{c}17.666 \\
\mathbf{b}_{ \pm} \pm 0.577\end{array}$ & $\begin{array}{c}203.666^{\mathrm{a}} \pm \\
2.081\end{array}$ & $\begin{array}{c}225.666^{c} \pm \\
0.570\end{array}$ & $\begin{array}{c}10.808^{c} \pm \\
0.952\end{array}$ \\
\hline $\begin{array}{l}\text { G(5)treated with } \\
20 \% \text { Citrus } \\
\text { aurantium }\end{array}$ & $\begin{array}{c}14.00^{\mathbf{b} \mathbf{c}_{ \pm}} \\
0.577\end{array}$ & $\begin{array}{c}203.333^{\mathrm{a}} \pm \\
4.932\end{array}$ & $\begin{array}{c}221.666^{\mathbf{b}} \pm \\
2.886\end{array}$ & $\begin{array}{l}9.035^{\mathbf{b}} \pm \\
1.226\end{array}$ \\
\hline
\end{tabular}

- Values are expressed as mean \pm SD.

- Values at the same column with different letters are significant at $\quad \mathrm{P}<0.05$.

Table (3) Intraperitoneal injection of a single dose of glycerol to rats at the last and the first days of the experiment caused nephrotoxicity manifested by significant $(\mathrm{P}<0.05)$ decreases in serum levels of total proteins (6.333 \pm 0.152 and $6.100 \pm 0.100$, respectively ) when compared with the normal (negative) control group $(6.900 \pm 0.173)$. As well as, there was a significant $(\mathrm{P}<$ $0.05)$ decrease in serum level of albumin in both control (+) positive $(2.333 \pm 0.070$ and $3.086 \pm 0.075$, respectively) compared to control (-) negative group $(3.893 \pm 0.090)$. Pretreatment and treatment with Citrus aurantium to glycerol-injected rats showed significant $(\mathrm{P}<0.05)$ 
Study the Protective and Therapeutic Effect of Bitter orange (Citrus aurantium .L) on Acute Renal Failure in Male Rats

improvement in all tested protein metabolism parameters, compared to both (+ve) groups.

Table (3): Effect of bitter orange(Citrus aurantium.L) on serum protein and albumin against glycerol induced nephrotoxicity in male rats.

\begin{tabular}{|c|c|c|}
\hline $\begin{array}{ll}\text { Groups } & \text { Parameters } \\
\end{array}$ & Protein & Albumin \\
\hline G(1) -ve control & $6.900^{\mathrm{a}} \pm 0.173$ & $3.893^{\mathrm{a}} \pm 0.090$ \\
\hline G(2)+veControl(pretreated) & $6.333^{b} \pm 0.152$ & $2.333^{\mathrm{d}} \pm 0.070$ \\
\hline G(3)+ve control(treated ) & $6.100^{d} \pm 0.100$ & $3.086^{\mathbf{c}} \pm 0.075$ \\
\hline $\begin{array}{l}\text { G(4)pretreated with } 20 \% \text { Citrus } \\
\text { Aurantium }\end{array}$ & $6.866^{\mathrm{a}} \pm 0.115$ & $3.316^{\mathbf{b}} \pm 0.0517$ \\
\hline $\begin{array}{l}\text { G(5)treated with } 20 \% \text { Citrus } \\
\text { Aurantium }\end{array}$ & $6.466^{\mathbf{b} c} \pm 0.152$ & $3.353^{\mathbf{b}} \pm 0.020$ \\
\hline
\end{tabular}

- Values are expressed as mean \pm SD.

- Values at the same column with different letters are significant at $\quad \mathrm{P}<0.05$.

Effect of pretreated and treated groups withcitrus aurantium on kidney function against Glycerol -induced nephrotoxicity in male rats is shown in table (4). The results revealed that, acute intoxication of rats by glycerol induced significant $(\mathrm{P}<0.05)$ elevation in serum level of urea

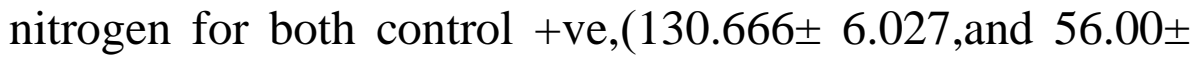
3.605 , respectively) compared to control (-) negative control group $(16.530 \pm 1.513)$. As well as, there was a significant $(\mathrm{P}<0.05)$ increase in serum level of creatinine in both control $(+)$ positive $(5.410 \pm 0.085$ and $1.583 \pm 0.144$, respectively) compared to control (-) negative group $(0.766 \pm$ 0.05). Fed of citrus aurantiumto glycerol injected rats, showed significant amelioration in all tested kidney function parameters. The Citrus aurantium lowers the elevated serum 
levels of urea nitrogen and creatinine. There were significant $(\mathrm{p}<0.05)$ difference between pretreated and treated groups and glycerol (+ve) group . On the other hand, there was a significant $(\mathrm{P}<0.05)$ increases in serum level of homocysteine in both +ve groups compared to control (-) negative group. Pretreated and treated with citrus aurantium caused a significant $(\mathrm{P}<0.05)$ decreases in serum homocysteine level compared to (+ve) group .

Table (4): Effect of bitter orange (Citrus aurantium.L) on serum urea nitrogen ,creatinine and homocysteine of against glycerol induced nephrotoxicity in male rats.

\begin{tabular}{|c|c|c|c|}
\hline Groups & $\begin{array}{c}\text { Urea nitrogen } \\
\text { mg/dl }\end{array}$ & $\begin{array}{c}\text { Creatinine } \\
\text { mg/dl }\end{array}$ & Homocysteine \\
\hline G(1) -ve control & $16.530^{c} \pm 1.513=$ & $0.766^{\mathbf{c}} \pm 0.05$ & $23.533^{\mathrm{b}} \pm 1.858$ \\
\hline $\begin{array}{l}\text { G(2)+ve } \\
\text { Control(pretread) }\end{array}$ & $130.666^{\mathrm{a}} \pm 6.027$ & $5.410^{\mathrm{a}} \pm 0.085$ & $37.500^{\mathrm{a}} \pm 1.500$ \\
\hline $\begin{array}{l}\text { G(3)+ve } \\
\text { control(treated) }\end{array}$ & $56.00^{\mathrm{a}} \pm 3.605$ & $1.583^{\mathrm{a}} \pm 0.144$ & $38.466^{\mathrm{a}} \pm 1.747$ \\
\hline $\begin{array}{l}\text { G(4)pretreated } \\
\text { with 20\% Citrus } \\
\text { Aurantium }\end{array}$ & $86.866^{c} \pm 12.859$ & $3.433^{b c} \pm 0.404$ & $17.800^{b} \pm 1.509$ \\
\hline $\begin{array}{l}\text { G(5)treated } \\
\text { with } 20 \% \text { Citrus } \\
\text { Aurantium }\end{array}$ & $21.663^{\mathbf{b}} \pm 2.497$ & $0.960^{\mathbf{b}} \pm 0.017$ & $20.233^{b \mathbf{c}} \pm 1.497$ \\
\hline
\end{tabular}

- Values are expressed as mean \pm SD.

- Values at the same column with different letters are significant at $\quad \mathrm{P}<0.05$.

Effect of pretreated and treated group with citrus aurantium on serum levels of ionic sodium, potassium , calcium, and Phosphorus against Glycerol -induced nephrotoxicity in male rats is shown in table (5) .

Data showed that glycerol(+ve) group had very highly significant $(\mathrm{P}<0.05)$ elevation in serum levels of $\mathrm{Na}, \mathrm{K}$ and $\mathrm{P}$ concomitant with significant $(\mathrm{P}<0.05)$ 
Study the Protective and Therapeutic Effect of Bitter orange (Citrus aurantium .L) on Acute Renal Failure in Male Rats

reduction in Ca compared to control (-) negative group. Pretreated and treated with citrus aurantium caused a marked protection evidenced by significant $(\mathrm{P}<0.05)$ reduction in serum levels $\mathrm{Na}, \mathrm{K}$ and $\mathrm{P}$ concomitant with significant $(\mathrm{P}<0.05)$ improvement in $\mathrm{Ca}$ level compared to (+ve) group. As well as there was a non significant change in pretreated and treated groups .

Table (5) : Effect of bitter orange (Citrus aurantium. L.) on serum levels of sodium, potassium, calcium, and

Phosphorus against glycerol induced nephrotoxicity in male rats.

\begin{tabular}{|c|c|c|c|c|}
\hline $\begin{array}{l}\text { Parameters } \\
\text { Groups }\end{array}$ & $\mathbf{N a}$ & $\mathbf{K}$ & Calcium & Phosphorus \\
\hline G(1) -ve control & $\begin{array}{c}133.333^{c} \pm \\
2.516 \\
\end{array}$ & $\begin{array}{c}2.530^{b} \pm \\
0.040\end{array}$ & $\begin{array}{c}12.300^{\mathrm{a}} \pm \\
0.793\end{array}$ & $3.153^{\mathbf{c}} \pm 0.192$ \\
\hline $\begin{array}{l}\text { G(2)+ve } \\
\text { Control (pretread) }\end{array}$ & $\begin{array}{c}166.00^{\mathrm{a}} \pm \\
2.00\end{array}$ & $\begin{array}{c}4.010^{\mathrm{a}} \pm \\
0.187\end{array}$ & $\begin{array}{c}9.300^{\mathbf{c}} \pm \\
0.529\end{array}$ & $4.663^{\mathrm{a}} \pm 0.230$ \\
\hline $\begin{array}{l}\mathbf{G ( 3 ) + v e} \\
\text { Control (treated) }\end{array}$ & $\begin{array}{c}161.00^{\mathrm{a}} \pm \\
4.582\end{array}$ & $\begin{array}{c}3.500^{\mathrm{a}} \pm \\
0.222\end{array}$ & $\begin{array}{c}8.400^{d} \pm \\
0.360\end{array}$ & $4.593^{\mathrm{a}} \pm 0.110$ \\
\hline $\begin{array}{l}\text { G(4)pretreated } \\
\text { with } 20 \% \text { Citrus } \\
\text { Aurantium }\end{array}$ & $\begin{array}{c}147.666^{\mathbf{b}} \pm \\
2.081\end{array}$ & $\begin{array}{c}3.313^{\mathbf{b}} \pm \\
0.344\end{array}$ & $\begin{array}{l}11.766^{\mathbf{a}} \\
{ }^{\mathbf{b}} \pm 0.152\end{array}$ & $3.853^{\mathbf{b}} \mathbf{c}_{ \pm 0} 0.343$ \\
\hline $\begin{array}{l}\text { G(5)treated with } \\
20 \% \text { Citrus } \\
\text { Aurantium }\end{array}$ & $\begin{array}{c}138.666^{c} \pm \\
5.131\end{array}$ & $\begin{array}{c}2.766^{\mathbf{b}} \pm \\
0.149\end{array}$ & $\begin{array}{c}9.600^{\mathbf{c d}} \pm \\
0.529\end{array}$ & $3.793^{\mathbf{b}} \pm 0.272$ \\
\hline
\end{tabular}

- Values are expressed as mean \pm SD.

- Values at the same column with different letters are significant at $\mathrm{P}<0.05$.

\section{Histopathological Investigations:}

Histological examination of kidneys of healthy rats showed the normal histological structure of renal parenchyma as illustrated in Photo (1). Kidney of rat from group 2 positive control group (pretreated) vacuolation of 
Fatma A. Hussein

epithelial lining renal tubules and presence of eosinophilic protein cast in the lumen of renal tubules Photo.(2). As well as Kidney of rat from group 3 positive control group (treated )showed tubular necrosis and calcification , photo.(3). Examination of kidneys of rats from group pretreated with $20 \%$ citrus aurantuim showed focal regenerated renal tubules,photo.(4).Whereas kidney of rat from rats fed on $20 \%$ citrus aurantuimshowing presence of eosinophilic protein cast in the lumen of renal tubules, photo.(5).

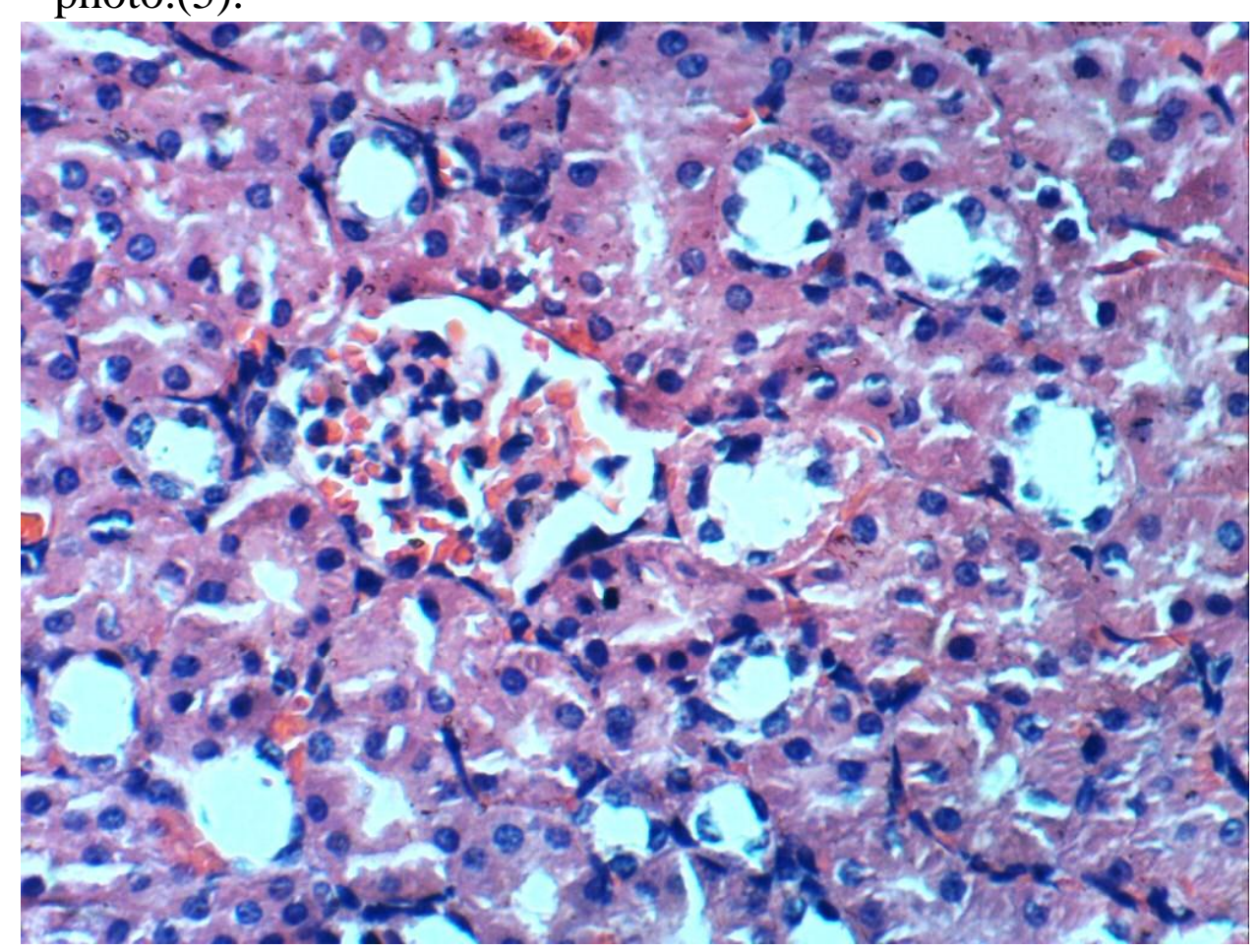

Photo. (1): Kidney of rats from Control negative group showing the normal histological structure of renal parenchyma (H \& E X 400) 
Study the Protective and Therapeutic Effect of Bitter orange (Citrus aurantium .L) on Acute Renal Failure in Male Rats

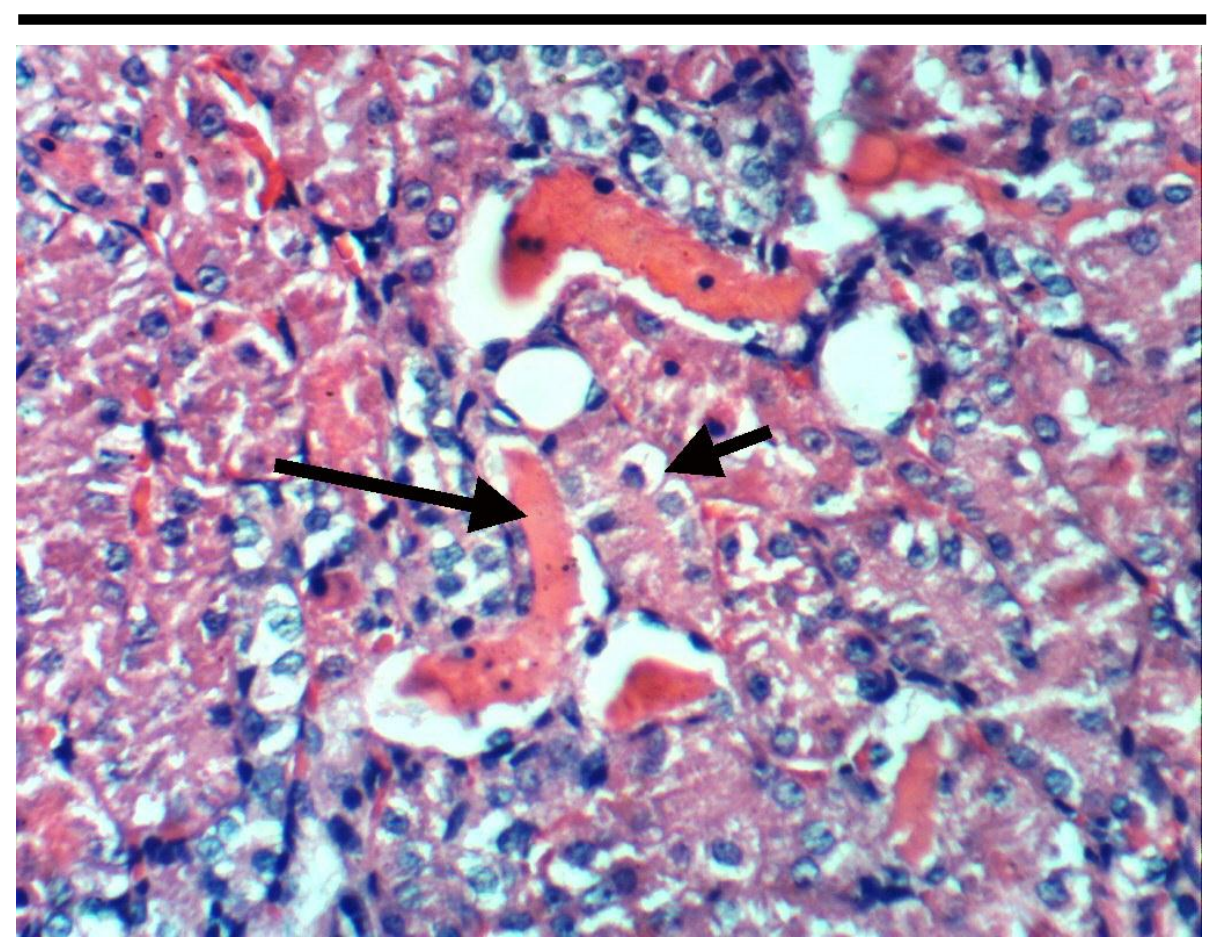

Photo. (2): Kidney of rats from positive pretreated control group showing vacuolation of epithelial lining renal tubules and presence of eosinophilic protein cast in the lumen of renal tubules (H \& E X 400). 
Fatma A. Hussein

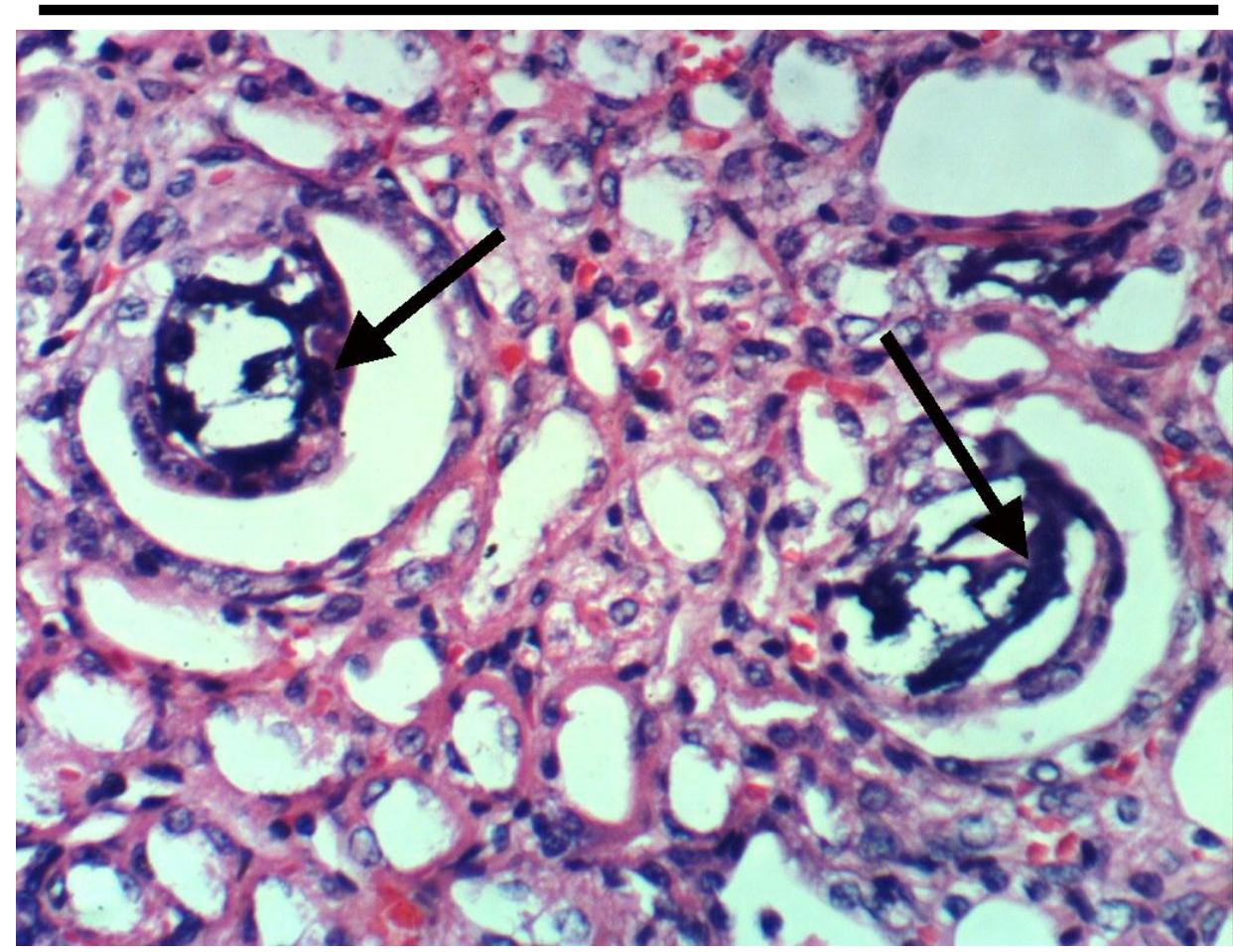

Photo. (3): Kidney of rat from group 3 positivetreated control group showing tubular necrosis and calcification (H \& E X 400) 
Study the Protective and Therapeutic Effect of Bitter orange (Citrus aurantium .L) on Acute Renal Failure in Male Rats

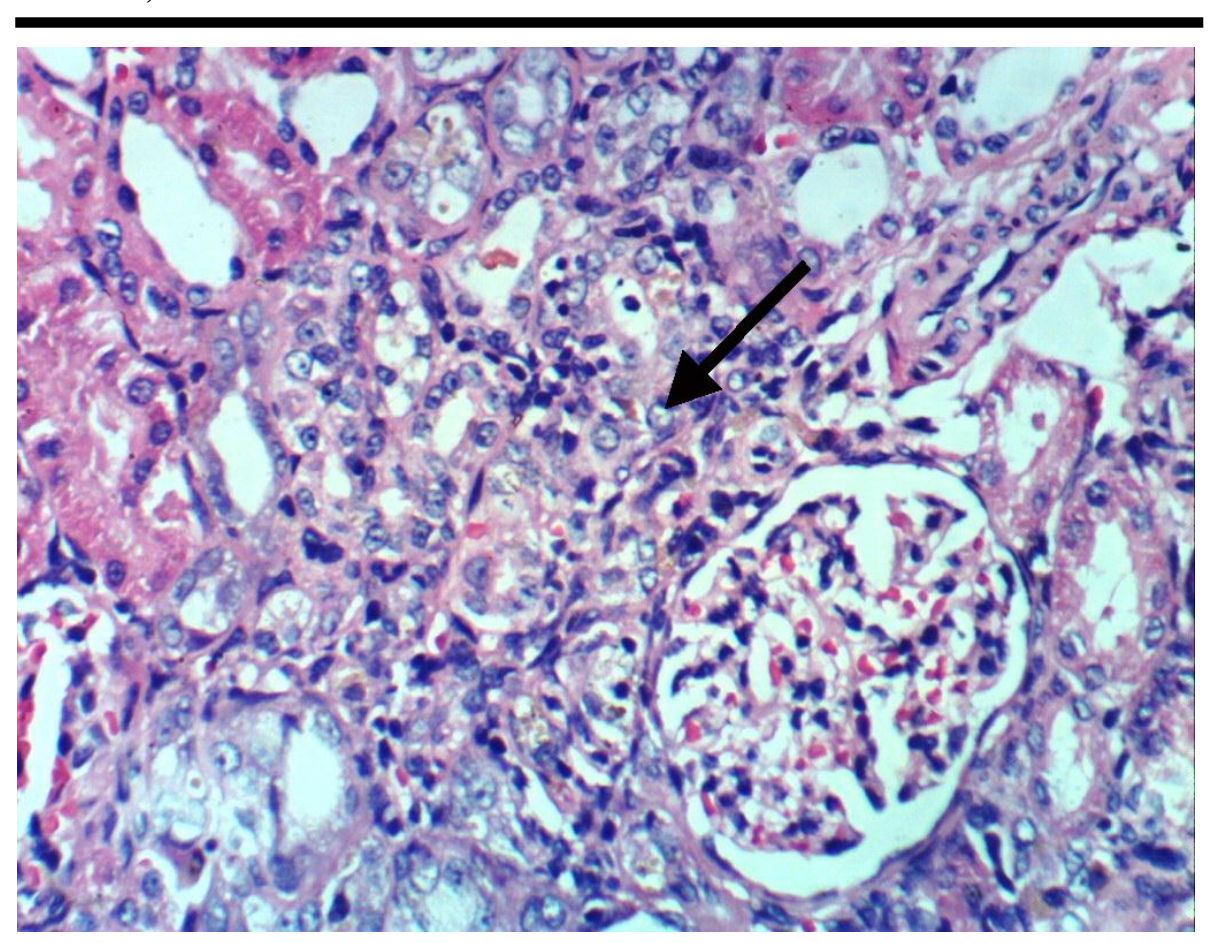

\section{Photo. (4): Kidney of rat from group 4 pretreated} with $20 \%$ citrus aurantuim showing focal regenerated renal tubules

(H \& E X 400). 
Fatma A. Hussein

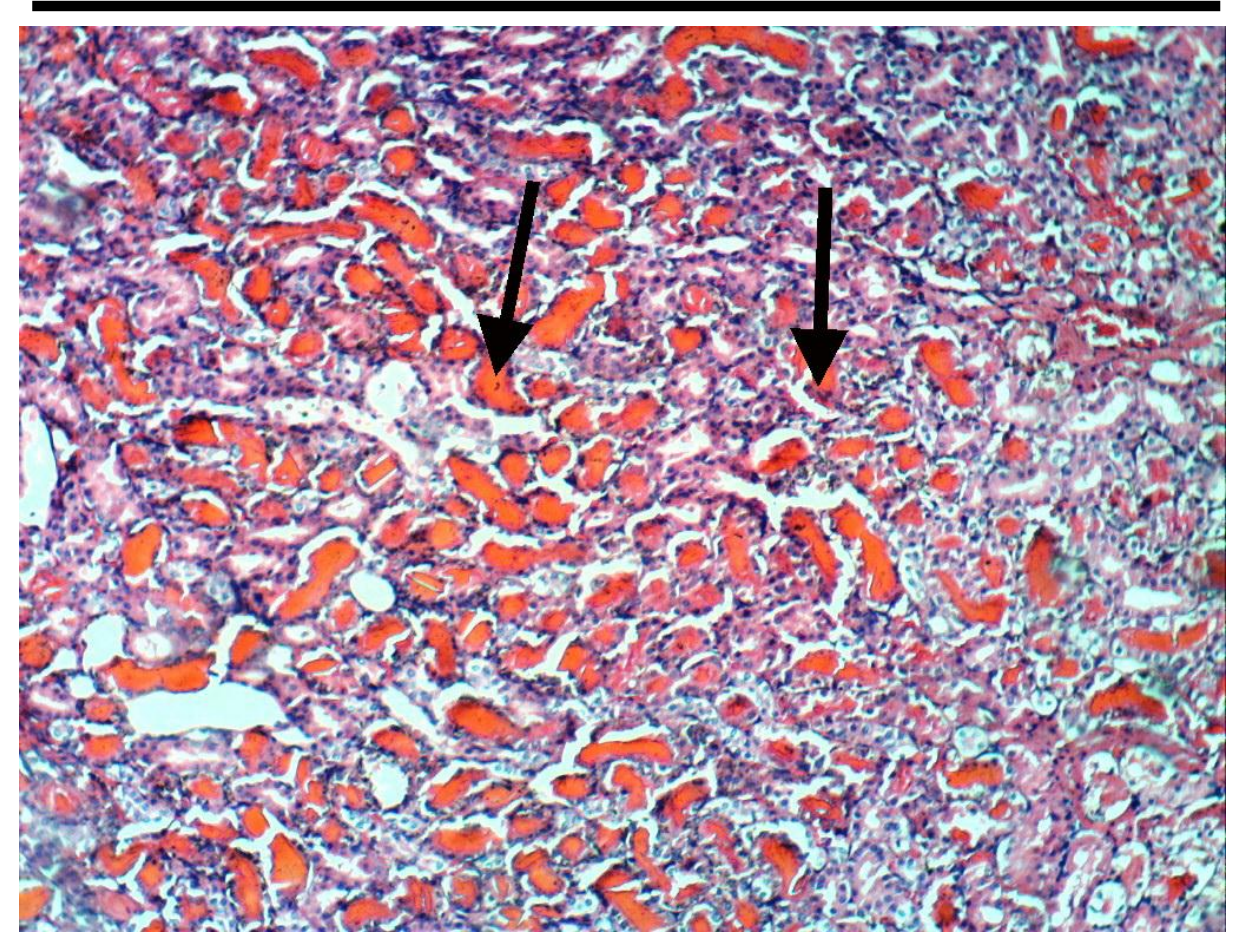

Photo. (5): Kidney of rat from group (5) $20 \%$ citrus urantuimshowing presence of eosinophilic protein cast in the lumen of renal tubules ( $H \& E X 100)$.

\section{DISCUSSION}

Nephrotoxicity represents a major health problem and accounts for high incidence among population all over the world Jainet al.,(2013). Glycerol-induced Acute Renal Failure is characterized by myoglobinuria,tubular necrosis Karamet al.,(1999).

Many plants contain antioxidant compounds and these compounds protect cells against the damaging effects of reactive oxygen species (ROS) such as single oxygen, superoxide, peroxyl radicals, hydrox radicals and 
peroxynitrite. Thus compounds or antioxidants that can scavenge free radicals have vital role in improvement of diseased conditions Fouad,et al.,(2014)

Body weight is the most sensitive indicator of adverse effects of chemical toxicants and xenobiotics. Glycerol induced statistical significant loss of body weight in glycerol groupcompared with control. This result was agree with Colker et al., (1999) that in a double-blind, placebocontrolled study of C. aurantium, caffeine and St John's Wort decreased total body weight with strict diet and exercise.and Ullah et al.,( 2014) who indicated that the combined administration of C. aurantiumat a dose of 200 $\mathrm{mg} / \mathrm{kg} / \mathrm{day}$ for a period of twenty one days significantly decreased in body weigh. Thus it may be explained by Haaz et al., (2006) who mentioned that antiobesity effect of $\mathrm{C}$. aurantium contains synephrine which is a stimulant with similar properties as caffeine and ephedrine. It claims to have similar effects by increasing energy expenditure, increasing metabolism, and suppressing appetite .The increase catabolism accompanied by anorexiaand the decrease of feed intake may be the causes of bodyweight loss seen in glycerol injection.

In the current study the results revealed that, serum level of total protein and albumin exhibited significant decrease in glycerol (+ve)group as compared with the corresponding values of thecontrol (-ve) group. These results were in the same line with Osfor ,et al.,(2013)who revealed that the groups of rats which received diets supplemented with $10 \%$ and $20 \%$ OrAP(orange albedo powder) for six weeks spontaneously were significantly increased on serum albumin.

The present results indicated that, there were signific antelevation in urea nitrogen and creatinine in glycerol 
(+ve) group as compared with control (-ve) group. These results were partially similar to those obtained by Moghaddam, et al.,(2010)Similar results were observed in the present study. Significant increase in blood urea nitrogen, serum creatinine, serum uric acid and decreased creatinine clearance in glycerol treated.

Pretreated and treated with Citrus aurantuim to glycerolinjected rats, showedsignificant amelioration in all tested kidney functionparameters as compared with the glycerol (+ve) group. Thepresent findings were in the same line with those reported byUllah, etal.,(2014)which used daily dose of $80 \mathrm{mg} / \mathrm{kg}$ of gentamicin to produce significant nephrotoxicity. Blood urea nitrogen and serum creatinine increased with significant fall in glomerular filteration, measured by creatinine clearance was observed with gentamicin.

Renal insufficiency is invariably accompanied by elevated plasma concentrations of the sulfur-containing and potentially vasculotoxic amino acid homocysteine. Glycerol induced statistical significant increases in homocysteine level, this finding was supported by van Guldener and Stehouwer.,(2005) who concluded that there is a strong relationship between glomerular filtration rate and plasma homocysteine concentration. Unlike creatinine, however, homocysteine is avidly reabsorbed in the renal tubules, and its urinary excretion is minimal. Also, the present findings were in the same line with those reported by van Guldener and Robinson., (2000)who mentioned that In patients with renal failure, hyperhomocysteinemia is a common feature. The mechanisms include reduced renal elimination of homocysteine and impaired nonrenal disposal, possibly because of inhibition of crucial enzymes in the methioninehomocysteine metabolism by the uremic milieu. Absolute or 
relative deficiencies of folate, vitamin B6, or vitamin B12 may also play a role. Several case-control and prospective studies have now indicated that hyperhomocystenemia is an independent risk factor for atherothrombotic disease in patients with predialysis and end-stage renal disease. Pretreated and treated with citrus aurantuim to glycerol injected rats, showed significant reduction in homocysteine level as compared with the glycerol (+ve) group.

The present study pretreated and treated of citrus aurantuim on kidney function against Glycerol -induced nephrotoxicity in male rats is shown decrease in serum level of $\mathrm{Na}$ and Kcompared to control (+)group.thepresent This was agree with with those reported byand Ullah et al.,(2014) which used daily dose of $80 \mathrm{mg} / \mathrm{kg}$ of gentamicin to produce significant nephrotoxicity. Who found Serum Na and Kdecreased significantly in all group when compared with control group on last day of experiment,and agree with Sudha and Venkatalakshmi.,(2012)..

Pretreated and treated with Citrus aurantuim to glycerolinjected rats, showedsignificant decresded in $\mathrm{Ca}$ and increased $\mathrm{p}$ compared with control (-ve) group.Ullah et al.,(2014) which used daily dose of $80 \mathrm{mg} / \mathrm{kg}$ of gentamicin to produce significant nephrotoxicity. Who found decreased in Serum calcium and increased significantly in serum phosphour on all group when compared with control group on last day of experiment,andagree with Sudha and Venkatalakshmi.,(2012).

In this study, the biochemical data were concordant with pathological findings. Examination of kidney sections of glycerol (+ve) group showed vacuolation of epithelial lining renal tubules and presence of eosinophilic protein cast in the lumen of renal tubules, tubular necrosis and calcification. This may be due to glycerol accumulation in 
renal cortex exhibited extensive proximal tubular necrosis throughout the corticomedullary region characterized by eosinophilic tubules with the remnants of karyolytic nuclei (40).Pretreated with citrus aurantuim remarkably minimized the structural changes in kidney, thus may be explained by antioxidative activity of ALE that may be attributed to its antioxidant constituents.

\section{CONCLUSIONS}

The current study demonstrated that the glycerol injection induces nephrotoxicity manifested by serum and urine biochemical changes and histopathological alterations in rats. Citrus aurantuim powder possesses significant nephroprotective and antioxidant effects. It has an ability to prevent and ameliorate the degeneration and tubular necrosis induced by glycerol in the kidney of rats. This is assessed by renal functional and histological examinations.

\section{Reference}

- Armitage,P. and Berry, G.(1987):Statistical Methods in Medical Reserearch. Blackwell ,Oxford,UK, pp.93-213.

- Bartholomew, R. J., and Delaney, A. M. (1966): Sulphonphthaleins as specific reagents for determination of albumin in serum. Proc. Aust. Ass. clin. Biochem., 1, 214.

- Calapai, G., Firenzuoli, F., Saitta, A., Squadrito, F., Arlotta, M. $\boldsymbol{R}$, and Costantino, G. (1999): Antiobesity and cardiovascular toxic effects of C. aurantium extracts in the rat: A preliminary report. Fitoterapia, 70: 586-592.

- Carleton,H.(1979):Histological Technique $.4^{\text {th }}$ Ed ., London.

- Castleman, M. (1995): The Healing Herbs: The Ultimate Guide to the Curative Power of Nature's Medicines. Bantam Books, New York.

- Colker, C. M., Kalman, D. S., Torina, G. C., Perlis, T., and Street, C. (1999):Effects of C. aurantium extract, caffeine and St. John's wort on body fat loss, lipid levels and mood states in overweight healthy adults. Curr. Ther. Res., 60: 145-153. 
Study the Protective and Therapeutic Effect of Bitter orange (Citrus aurantium .L) on Acute Renal Failure in Male Rats

- Fang, F., Dong, M., and Zhu, H. (2003): Effect of C. aurantium extract on L-type calcium currents in ventricular myocytes of single guinea pigs. Hunan. Yi. Ke. Da. Xue. Xue. Bao., 4: 353-356.

- Fellers, P.J., Nikdel, S., and Lee, H. S. (August 1990). "Nutrient content and nutrition labeling of several processed Florida citrus juice products". Journal of the American Dietetic Association 90 (8): 1079-84.

- Fossati, P., Prenciple, L. and Berti, G.(1980): Enzymatic colorimetric method for determination of uric acid in serum Clin.Chem.26(2):227-273.

- Fouad, A.A.,Albuali, W.H.,Zahran,A.,and Gomaa, W. (2014):Protective effect of naringenin against gentamicin induced nephrotoxicity in rats Environ. Toxicol Pharmacol. , 38(2):420429.

- Gange, C.A., Madias, C., Felix-Getzik, E. M., Weintraub, A.R., and Estes, N.A., (2006).Variant angina associated with bitter orange in a dietary supplement. Mayo. Clinic. Proc., 81: 545-548.

- Hess, A.M., and Sullivan, D. L. (2005): Potential for toxicity with use of bitter orange extract and guarana for weight loss. Ann. pharmacother., 39: 574-575.

- Houghton, D. C., Plamp, C. E., DeFehr, J. M., Bennett, W. M., Porter, G., and Gilbert, D. N. (1978): Gentamicin and tobramycin nephrotoxicity: A morphologic and functional comparison in the rat. Am. J. Pathol., 93: 137-152.

- Husdan, H., and Rapoport, A.(1968):Estimation of creatinine by the Jaffe reaction. A comparison of three methods. Clin Chem. Mar;14(3):222-238.

- Jain , A.,Nahata,A., and Singhai,A.K.(2013):Effect of Tephrosia Purpurea (L.) leaves on gentamicin induced nephrotoxicity in rats . Sci.Pharm.,81(4):1071-1087.

- Jia, Z.S., Tang, M.C., Wu J.M. (1999): The determination of flavonoid contents in mulberry and their scavenging effects on superoxide radicals. Food Chem, 64, 555-559.

- Jyotsna, A., and Saonere, S. (2011): An overview of C. aurantium used in treatment of various diseases. Afr. J. Plant Sci., 5: 390-395.

- Karam, H., Bruneval, P., Clozel, J.P., Loffler, B.M., Bariety, J., and Clozel, M.(1999):Role of endothelin in ARF due to rhabdomylosis in rats. J PharmacolExpTher, 274, 481-486. 
- Kirbaslar, F. G., tavman, A., dulger, B., and turker, G. (2009): Antimicrobial activity of Turkish Citrus peel oils. Pak. J. Bot., 41: 3207-3212.

- Kubo, K., Kiyose, C., Ogino, S. and Saito, M .(2005):Suppressive effect of C. aurantium against body fat accumulation and its safety. J. Clin. Biochem. Nut., 36: 1-11.

- Midhun, C, Korrapati., Brooke, E, Shaner., and Rick, G, Schnellmann.( 2012):Recovery from Glycerol-Induced Acute Kidney Injury Is Accelerated by Suramin.Apr; 341(1): 126-136. doi: 10.1124/jpet.111.190249PMCID: PMC3310704.

- Moghaddam, A.H., Javaheri, M., Nabavi, S.F., Mahdavi, M.R., Nabavi, S .M., and Ebrahimzadeh M.A. (2010). Protective role of pleurotus porrigens (angel's wings) against gentamicin-induced nephrotoxicity in mice. Europ. Rev. Med. Pharmacol. Sci., 14: 1011-1014.

- Monsef-Esfahani, H. R., Amanzade, Y., Alhani, Z., Hajimehdipour, H., and Faramarzi, M. A. (2004):GC/MS analysis of C. aurantium L. hydrolate and its comparison with the commercial samples. Iranian J. Pharm. Res., 3: 177-179.

- Nobuhito , S., Takahiro, O., Nobuo, H.,Tokuzo, M. and Akira, Y.(1999):Influence of glycerol -induced acute renal failure on the pharmacokinetics of cycloporin in rats.J. Pharma. Pharmacol, 51:397-404.

- Patton, C.J.,and Crouch, S . R.(1977): Enzymatic colorimetric method for determination of urea in serum .Anal . Chem. 49: 464469.

- Platt, R. (2000). "Current concepts in optimum nutrition for cardiovascular disease". PrevCardiol 3 (2): 83-7.

- Reeves, P., Nielsen , F.,and Fahmy, G.(1993): Purified diets for laboratory rodent :Final report of the American Institute of Nutrition and Hoc writing committee on the reformulation of the AIN-76 a rodent diet .J. Nutrtr ., $123: 1939-1951$.

- Satoh, Y., Tashiro, S., Satoh, M., Fujimoto, Y., Xu, J.Y., and Ikekawa, $T$.(1996): Studies on the bioactive constituents of Aurantii Fructus Immaturus. Yakugaku Zasshi, 116: 244-250.

- Savic V, Vlahovic P, Djordjevic V, Mitic-Zlatkovic M, Avramovic V, Stefanovic, V.(2002): Nephroprotective effects of pentoxifylline 
Study the Protective and Therapeutic Effect of Bitter orange (Citrus aurantium .L) on Acute Renal Failure in Male Rats

in experimental myoglobinuric acute renal failure. Pathologie Biologie, 50, 599-607.

- Scedecor,G. W., and Cochran, W. G.(1976):Statistical Method: $6^{\text {th }}$ ed., Lowa State University, Press, Ames, lowa. U. S. A.

- Sharpe, P.A., Granner, M.L., Conway, J. M., Ainsworth, B. E., and Dobre, M. (2006): Availability of weight-loss supplements: Results of an audit of retail outlets in a southeastern city. J. Am. Diabetic Assoc., 106: 2045- 2051.

- Singleton, V., and Rossi, J. A.(1965):Colorimetry of total phenolics with phosphomolybdic- phosphotungstic acid reagents. Am j Enol vitic 16:144-158.

- Siskos, E. P., Konstantopoulou, M. A., and Mazomenos, B. E. (2009):Insecticidal activity of $C$. aurantium peel extract against Bactrocera oleae and Ceratitis capitata adults (Diptera: Tephritidae) J. App. Entomol., 133: 108-116.

- Sudha M and VenkatalakshmiP. ffect of Citrus aurantium Linn ., in paroxetine induced hyponatremia in albino mice.Journal of Chemical and Pharmaceutical Research, 2012, 4(4):2043-2045.

- Télez, M., Ortiz-Lastra, E., Gonzalez, A.J., Flores, P., Huerta, I., and Ramírez, J.M.(2010): Assessment of the genotoxicity of atenolol in human peripheral blood lymphocytes: correlation between chromosomal fragility and content of micronuclei. Mutat Res; 695(1-2): 46-54.

- Ullah, N., Khan, M.A., Khan, T., Ahmad, W'. (2014): ephroprotectives potentials of Citrus aurantium:a prospective pharmacological study on experimentalmodels. Pak J Pharm Sci. May;27(3):505-10.

- Ueland, P.M., Refsum., H., Stabler, S. Malinow , M .R. , Andersson ,A.,and Allen,R.H.(1993)Total homocysteine in plasma or serum: metho ds and clinical applications. Clin Chem. 1993 Sep; 39 (9):1764-79

- van Guldener, C., Robinson, K.(2000) :Homocysteine and renal disease.Semin Thromb Hemost. ;26(3):313-24.

- van Guldener C, and Stehouwer, C. D. (2005): Homocysteine and methionine metabolism in renal failure. May;5(2):201-8.

- Weichselbaum, T.E. (1946): Estimation of serum total protein by Biruet method. Am J Clin Path. 16: 40-48.

- Zhang, J.L., Rusinek, H.,Chandarana, h. and Lee, V.S.(2013):Functional MRI of the kidneys . kidney Int.:37(2):28292 . 